Kinestetik : Jurnal Ilmiah Pendidikan Jasmani 5 (3) (2021)

Kinestetik : Jurnal Ilmiah Pendidikan Jasmani

https://ejournal.unib.ac.id/index.php/kinestetik/index

DOI : 10.33369/jk.v5i3.17500

\title{
ANXIETY AND CONCENTRATION OF TENNIS ATHLETE
}

\section{Rices Jatra $^{1 *}$, Septian Raibowo ${ }^{2}$}

${ }^{1}$ Sport Education, Islamic Universitas Riau, Riau, Indonesia

${ }^{2}$ Physical Education, Universitas Bengkulu, Bengkulu, Indonesia

\section{Article Info}

Article History :

Received : August 2021

Revised : September 2021

Accepted : September 2021

Available online : September 2021

\section{Keywords:}

Anxiety, Concentration, Tennis Athlete

\begin{abstract}
The purpose of this research to understand the correlation between anxiety and the concentration of tennis athletes. This study does not use certain sampling technique because it is a population research. So all tennis athletes who enter the qualification round in the tournament "Piala Rektor UNP \& Dirut Bank Nagari 2021" tournament totaling 50 athletes were chosen to be research subjects. Measurement of anxiety variables on the sports anxiety scale and concentration variables using a concentration training grid. Analysis of the data used is product moment correlation. Analysis of the data used is product moment correlation. Data analysis shows a correlation coefficient of 0.784 and is included in the strong category and contributes to the correlation between variables of 0.64 or $64 \%$. From the value of the correlation coefficient is in the strong category. That is, if the level of anxiety is high, the level of concentration of tennis athletes will be lower and vice versa, an increase in concentration will be followed by a decrease in anxiety.
\end{abstract}

\begin{tabular}{llr}
\hline Corresponding address & : Jl. Kaharuddin Nasution 113 Pekanbaru & ISSN 2685-6514 (Online) \\
*Corresponding email & : ricesjatra@edu.uir.ac.id & ISSN 2477-331X (Print)
\end{tabular}




\section{INTRODUCTION}

Sport is one of the manifestations of efforts to improve the quality of Indonesian people through the formation of high character, character, discipline and sportsmanship, as well as increasing achievements that can evoke a sense of national pride. Sports activities cover various sports such as athletics (Syafrial et al., 2020), games (Ilahi et al., 2020) water sports and martial arts.

The most popular sport in the community is tennis. On the Asian continent, tennis is ranked fifth in a row behind football, badminton, swimming and basketball (Hakuhodo Inc., 2012). Then in the United States, tennis is included in the top five sports that are often played with basketball in the first place (NPR et al., 2015). Of course, this is enough to describe the existence of court tennis, which is very popular with people in the world, as well as for achievement, tennis is also useful for improving physical fitness. Tennis courts make a significant contribution to the health and fitness of a person (Raibowo et al., 2020).

Indonesia is one of several countries in the Asian Region that has quite good individual sports achievements, including tennis. It was recorded in the 2018 Asian Games multi event which was held in Indonesia, the field tennis sport successfully contributed a gold medal in the mix double match number (Amni et al., 2019)

In the world of sports, competition is an event for athletes to show the results of the training process that has been carried out so far and is an arena for achievement. The achievements obtained by an athlete are a series of several stages that they have carried out programmatically and systematically (Arifianto et al., 2021) as well as many factors that can influence this achievement (Hardiyono, 2020), both internal factors from the athlete's own ability, the training program designed (Raibowo, Ilahi, et al., 2021), as well as nutritional intake and nutrition (Putri et al., 2020). While external factors are parents, crowd pressure during matches, sports management and referee leadership (Raibowo, Jatra, et al., 2021). These influencing factors can be a stressor for athletes (Sari \& Kurniawan, 2018) which will have an impact on the level of anxiety and concentration felt by athletes.

The game of tennis is a game that is played on a rectangular court and is divided into 2 (two) parts by the net and using tools in the form of a racket and ball (Arifianto \& Raibowo, 2020). In the game the ball is hit over the net and each player tries to turn off the ball on the opponent's playing field (Siahaan, 2017), The idea of playing tennis is to turn off the ball in the opponent's area and try to hit the opponent's area (Dayani et al., 2020). With the characteristics of these sports, the game is played with fast intensity and high tension, so it needs carefulness and thoroughness in making 
decisions such as whether the game will be run at a fast or slow tempo. As a result, the right decision making in the middle of such an atmosphere is right to do (Larkin et al., 2011). Concentration is needed for athletes in accordance with sports that specifically require the application of increasing accuracy.

An athlete also needs high concentration so as not to be late in making decisions, acting hesitantly or making wrong decisions that will result in fear or self-deception and result in losing points in each game. Concentration is a person's ability to focus his attention and mind only on the information that is important to the success of his performance in leading the game (Jannah, 2017). When concentrating, he will sort out information that does not facilitate his performance and focus only on relevant information. concentration is an important mental aspect for athlete's success in displaying best performance. Without the concentration well, athletes can do various error in performance like failed display the techniques that have been learned (Eysenck \& Keane, 2015). The mistakes that make athlete's performance is not optimal it doesn't just happen when athletes be in a match situation or competition, but also during training (Sholikhin et al., 2019)

In tennis, there are many factors that can affect the outcome of a match, namely physical, technical, tactical, mental \& strategy (Bakhtiar \& Ballard, 2015), These 5 (five) factors are interrelated and support each other. Factors that influence achievement include physical/biomotor conditions, the ability to master techniques and tactics, as well as psychological factors (Alim, 2018).

A athelete must have a low level of anxiety and should be able to master it (Jannah, 2017), however high or low anxiety depends on factors such as: skill level and experience (Tangkudung, 2018).

Anxiety in dealing with a match can be divided into 2 types (Tangkudung, 2018) state anxiety (state-A) and trait anxiety (trait-A). Bebetsos et al (2013) further explained that anxiety as a state anxiety or trait anxiety has two components, namely cognitive anxiety and somatic anxiety. Furthermore, cognitive anxiety is a mental component, namely the emergence of anxiety due to a fear of negative social assessment, fear of failure and loss of self-esteem. Somatic anxiety is a physical component and 
reflects physiological responses, such as increased heart rate, breathing and muscle tension. Somatic anxiety refers to individual physiological arousal arrests that have negative characteristics, such as increased pulse rate, abdominal pain, sweating and others. Indicators that can be used as an anxiety can be seen from physical changes (Komaruddin, 2017).

$$
\text { Anxiety is actually a }
$$

psychological aspects that are normally experienced by a person (Jannah, 2016). However, for athletes, if the anxiety is experienced in a high-intensity match and the athlete is less able to manage it, then anxiety can hinder the athlete's performance (Hasanah \& Refanthira, 2020). The level of anxiety is also influenced by the level of confidence of a player. Players who naturally have high levels of self-confidence have lower levels of anxiety compared to athletes who have low self-confidence (Hagan et al., 2017)

In addition to psychological factors (anxiety and concentration) the athlete's physical condition affects decision making in every action in the match (Raibowo, Ilahi, et al., 2021). Poor physical fitness and impaired psychological condition due to anxiety felt by the athlete's can hinder concentration so that it will be able to impact decision making. Therefore, this study was conducted to determine whether or not there is a correlation between anxiety and concentration on tennis athlete's.

\section{METHODS}

This study does not use certain sampling technique because it is a population research. So all tennis athletes who enter the qualification round in the tournament "Piala Rektor UNP \& Dirut Bank Nagari 2021" tournament totaling 50 athletes were chosen to be research subjects.

The number of subjects in this study were 50 tennis athletes. The spread of questionnaires and concentration tests was used as a data collection technique in this study. Research instruments on the aspect of anxiety using a questionnaire totaling 35 points of questions with obtained Validity 0.83 and Realibility 0.65 then concentration research instrument using Grid concentration exercise, which is a concentration test table containing numbers 00-99 arranged randomly, with respondents sorting numbers in a runtut for 1 minute (Tache et al., 2017). The more numbers that are successfully sorted, the higher the concentration (Sin \& Aprinanda, 2020).

Table 1. Validity \&Realibility

\begin{tabular}{ccc}
\hline Validity & 0.83 & Very High \\
\hline $\begin{array}{c}\text { Cronbach's } \\
\text { Alpa }\end{array}$ & 0.65 & Reliable \\
\hline
\end{tabular}


The data analysis technique in this study used Product Moment Correlation analysis test to find the level of correlation coefficient between variables (Widiastuti et al., 2017), but before that a simple regression analysis and prerequisite analysis test will be conducted. To test the normality of the data using lilifors test method with comparison of $\mathrm{L}^{\text {count }}$ and $\mathrm{L}^{\text {tabel }}$ as well as simple linear regression analysis. With equations

$$
\begin{gathered}
Y=a+b x \\
Y=81.4+4.03 x
\end{gathered}
$$

\section{RESULTS}

Based on the data analysis conducted, obtained the results of the data normality test of each variable

Table 2. Normality Test Results

\begin{tabular}{cc}
\hline Variable & Sig \\
\hline Anxiety & 0.92 \\
\hline Concentration & 0.07 \\
\hline
\end{tabular}

$\alpha=0.05$

From the data obtained sig $>0.05$ then data is categorized as normal.

From the results of the simple linearity test, the Fcount value is 87.01 which will provide an explanation of the calculation of whether the $X$ variable has a significant effect on the $\mathrm{Y}$ variable by seeing whether the significance of $F$ is smaller than the $\alpha$ (0.05). The significance value of $\mathrm{F}=0.02<0.05$ then the $\mathrm{X}$ variable has a significant influence on the $\mathrm{Y}$ variable.
Then the correlation data between variables obtained a yield 0.784

Table 3. Product Momen Correlation Results

\begin{tabular}{cc}
\hline $\mathrm{R}$ & $R$ Square \\
\hline 0.784 & 0,64 \\
\hline
\end{tabular}

Based on data Table 3 above, it can be seen that the contribution of anxiety predictor variable concentration variable is $64 \%$, then the correlation rate in both variables is obtained by a value of 0.784 with a strong classification.

Table 3. Product Momen Correlation Results

\begin{tabular}{cc}
\hline $\begin{array}{c}\text { Correlation } \\
\text { coeficiente } \\
\text { interval }\end{array}$ & Category \\
\hline $0,00-0,199$ & Very Weak \\
\hline $0,20-0,399$ & Weak \\
\hline $0,40-0,599$ & Moderate \\
\hline $0,60-0,799$ & Strong \\
\hline $0,80-1,00$ & Very Strong \\
\hline
\end{tabular}

(Prabowo et al., 2020)

\section{DISCUSSION}

\section{Concentration plays a very} important role in a match, if disturbed it will cause problems, especially when players are competing with a high level of accuracy and concentration and make decisions quickly and in conditions of high match tension. Concentration is one of the psychological factors that affect performance (Triananda et al., 2021; Wahib et al., 2021)

Concentration is an important factor that must be owned by a professional athlete, many factors affect the level of concentration of an athlete, 
including lifestyle, patterns of daily habits such as sleep quality. Poor sleep quality has negative effects including headches and difficulty (O'callaghan et al., 2018; Oh et al., 2018).

Ways that can be done by a tennis athlete to maintain concentration, should do and run a healthy lifestyle and do exercises that can improve concentration. Concentration training that can be done is to train attention relaxation which is a technique to reduce anxiety, stress and stress so that it can maximize the use of the sense of sight (Mulyana et al., 2013). In addition, doing image training can increase concentration and reduce anxiety (Haghkhah et al., 2014). Imaging exercises can produce a better psychological response, which can stimulate the emergence of more endorphins (Septiyanto \& Suharjana, 2016), thus providing a calm and comfortable effect when competing. This relaxing effect will help the athlete to concentrate better (Pineschi \& di Pietro, 2013; Raibowo, Jatra, et al., 2021)

The type of exercise also contributes to anxiety levels. Tennis is an individual sport. Individual sports create greater pressure than team sports (Pluhar et al., 2019). This is natural because the feeling of having a friend will make you calmer and less focused on him. The last thing that affects the level of anxiety is gender. According to several studies, female athletes are more likely to have higher levels of anxiety than male athletes (Correia \& Rosado, 2019)

Furthermore, anxiety has its own role on the appearance of an athlete when competing. In general, athletes who experience anxiety are characterized by symptoms that are usually followed by tension or stress (Alim, 2018; Jannah, 2017; Raibowo, Jatra, et al., 2021). Indicators that can be used as levels of anxiety can be seen from physical and psychological changes, including increased pulse, abdominal pain, sweating (Bebetsos et al., 2013) changes in behavior, restlessness, difficulty sleeping, changes in breathing rhythm, unstable emotions and decreased selfconfidence (Komaruddin, 2017)

An effective solution to dealing with anxiety is relaxation exercises. Relaxation exercises are very effective given to someone who is in a state of tension (Tangkudung, 2018). Relaxation exercises and psychingup can be combined with music which is often called pre-task music (Karageorghis \& Priest, 2012). Listening to music before a task may have a stimulating or positive effect (Terry \& Karageorghis, 2011). The results of research on relaxation and psyching up techniques conducted by the Brazilian Olympic Committee show that these techniques have been shown to help a person to manage anxiety and arousal levels, thereby improving performance (Pineschi \& di Pietro, 2013).

Then in addition to doing relaxation exercises, to manage anxiety is to do self talk techniques (Raibowo, Jatra, et al., 2021). A successful self-talk exercise is when one is able to get rid of doubtful and fearful thoughts and replace them with optimistic speech and sentences (Tangkudung, 2018). 
Based on this, it is clear that anxiety and concentration are important things that must be managed and maintained by an athlete. An athlete must have a high level of concentration so as not to be late in taking action, act hesitantly or take the wrong action that will cause the athlete to experience anxiety or fear during competition which will affect the athlete's appearance.

\section{CONCLUSION}

Based on data analysis, it can be concluded that the level of concentration of tennis athletes has a significant relationship with the level of anxiety of tennis athletes.

The correlation coefficient value obtained is 0.784 and is included in the strong category and contributes to the correlation between variables of 0.64 or $64 \%$. From the value of the correlation coefficient, it can be interpreted that if the level of anxiety is high, the lower the level of concentration of tennis athletes and vice versa, the increase in concentration will be followed by a decrease in anxiety of tennis athletes.

\section{REFERENCES}

Alim, A. (2018). Hubungan Motivasi , Attitude, Anxiety dan Self Efficacy Terhadap Prestasi Atlet Tenis Lapangan Level Junior dan Senior. Medikora, XVII(2), 83-90. https://doi.org/10.21831/medikora.v17i 2.29179

Amni, H., Sulaiman, I., \& Hernawan. (2019). Model Latihan Keterampilan Groundstroke Pada Cabang Olahraga
Tenis Lapangan. Jurnal Terapan Ilmu Keolahragaan, 4(2), 91-98. https://doi.org/10.17509/jtikor.v4i2.189 68

Arifianto, I., \& Raibowo, S. (2020). Model Latihan Koordinasi dalam Bentuk Video Menggunakan Variasi Tekanan Bola Untuk Atlet Tenis Lapangan Tingkat Yunior. STAND: Journal Sport Teaching and Development, 1, 49-55. https://doi.org//10.36456/jstand.v1i2.2671

Arifianto, I., Raibowo, S., \& Jatra, R. (2021). Groundstroke Training Games Dalam Bentuk Video untuk Atlet Junior Tenis Lapangan. Jurnal Menssana, 6(1), 12 22. https://doi.org/10.24036/MensSana.060 12021.18

Bakhtiar, S., \& Ballard, R. J. (2015). Teori Action Method, Strength Condition dan Penerapannya dalam PEMBINAAN PRESTASI TENIS (Damrah, A. G. Tamsin, \& Safei (eds.); 1st ed.). Wineka Media.

Bebetsos, E., Zouboulias, S., Antoniou, P., \& Kourtesis, T. (2013). Do anxiety, anger and aggression differentiate elite waterpolo players? Journal of Physical Education and Sport, 13(2), 209-212. https://doi.org/10.7752/jpes.2013.02035

Correia, M., \& Rosado, A. (2019). Anxiety in athletes: Gender and type of sport differences. International Journal of Psychological Research, 12(1), 9-17. https://doi.org/10.21500/20112084.355 2

Dayani, H., Yennes, R., Masrun, \& Setiawan, Y. (2020). Studi Minat Mahasiswa Terhadap Olahraga Tenis Lapangan. Jurnal Patriot, 2(3), 9-16. https://doi.org/10.4135/9781412984683 .n2

Eysenck, M. W., \& Keane, M. T. (2015). Cognitive Psychology: A Student's Handbook (7th ed.). Psychology Press.

Hagan, J. E., Pollmann, D., \& Schack, T. (2017). Elite athletes' in-event competitive anxiety responses and psychological skills usage under differing conditions. Frontiers in Psychology, $8, \quad 1-11$. https://doi.org/10.3389/fpsyg.2017.022 
80

Haghkhah, A., Sohrabi, M., Hamidreza, T. T., Ghalehroudhkani, H. H., \& Tabar, M. G. (2014). The Effect of Mental Imagery Focus of Attention on Performance and Learning of Children Dart Throwing Skill. International Journal of Sport Studies, $\quad 4(1)$, 161-167. www.ijssjournal.com

Hakuhodo Inc. (2012). Sports Popular in 14 Asian Countries. Global Habit, 3(1), 110.

Hardiyono, B. (2020). Tingkat Kecemasan Sebelum Bertanding dan Percaya Diri Pada Saat Bertanding Atlet Pelatda Pengprov FPTIi Sumatera Selatan. Kinestetik: Jurnal Ilmiah Pendidikan Jasmani, 4(1), 47-54. https://doi.org/10.33369/jk.v4i1.10399

Hasanah, U., \& Refanthira, N. (2020). Human Problems: Competitive Anxiety in Sport Performer and Various Treatments to Reduce It. 5th ASEAN Conference on Psychologu, Counseling, and Humanities (ACPH 2019), 395, 144148.

https://doi.org/10.2991/assehr.k.200120 .031

Ilahi, B. R., Syafrial, \& Hiasa, F. (2020). Implementasi Model Pembelajaran Kooperatif Tipe Numbered Heads Together pada Mahasiswa Pendidikan Jasmani Universitas Bengkulu. Halaman Olahraga Nusantara (Jurnal Ilmu Keolahragaan), 3(2), 207-213. https://doi.org/10.31851/hon.v3i2.4858

Jannah, M. (2016). Kecemasan olahraga: Teori, Pengukuran dan Latihan Mental. UNESA Press.

Jannah, M. (2017). Kecemasan dan Konsentrasi Pada Atlet Panahan. Jurnal Psikologi Teori Dan Terapan, 8(1), 5360. https://doi.org/10.26740/jptt.v8n1.p5360

Karageorghis, C. I., \& Priest, D. L. (2012). Music in the exercise domain: a review and synthesis (Part II). Journal International Review of Sport and Exercise Psychology, 5(1), 67-84. https://doi.org/10.1080/1750984X.2011 .631027

Komaruddin. (2017). Psikologi Olahraga
Latihan Keterampilan Mental dalam Olahraga Kompetitif (V). Remaja Rosdakarya.

Larkin, P., Berry, H., \& Dawson, B. (2011). Assesment of Umpire Perceptual and Decision-making Skill in Austarlian Football. Journal of Science and Medicine in Sport, 14(2011), e86-e87. https://doi.org/10.1016/j.jsams.2011.11. 178

Mulyana, O. P., Izzati, U. A., \& Puspitadewi, N. W. S. (2013). Penerapan Relaksasi Atensi Untuk Meningkatkan Konsentrasi Belajar Pada Siswa SMK. Jurnal Psikologi Teori Dan Terapan, 3(2), 103. https://doi.org/10.26740/jptt.v3n2.p103112

NPR, Robert Wood Johnson Foundation, \& Harvard T.H. Chan School of Public Health. (2015). Sports and Health in America. June, 73.

O'callaghan, F., Muurlink, O., \& Reid, N. (2018). Effects of caffeine on sleep quality and daytime functioning. Risk Management and Healthcare Policy, 11, 263-271. https://doi.org/10.2147/RMHP.S156404

Oh, J. H., Cho, S. J., Kim, W. J., Yang, K. I., Yun, C. H., \& Chu, M. K. (2018). Insufficient sleep in tension-type headache: A population study. Journal of Clinical Neurology (Korea), 14(4), 566-573.

https://doi.org/10.3988/jcn.2018.14.4.5 66

Pineschi, G., \& di Pietro, A. (2013). Anxiety Management Through Psychophysiological Techniques: Relaxation and Psyching-up in Sport. Journal of Sport Psychology in Action, 4(3), 181-190. https://doi.org/10.1080/21520704.2013. 820247

Pluhar, E., McCracken, C., Griffith, K. L., Christino, M. A., Sugimoto, D., \& Meehan, W. P. (2019). Team sport athletes may be less likely to suffer anxiety or depression than individual sport athletes. Journal of Sports Science and Medicine, 18(3), 490-496.

Prabowo, A., Waluyo, Marsiyem, \& Ihsan, N. (2020). The Relation of Togok 
Flexibility and Limb Muscle Power to Perform Power Jump Heading on Football Extracurricular of SMK Negeri 2 Muara Enim Students. Proceedings of the 1st Progress in Social Sciences, Humanities and Education Research Symposium (PSSHERS 2019), 464, 960962.

https://doi.org/10.2991/assehr.k.200824 .213

Putri, L. P., Septri, Zamroni, Oktarifaldi, Syahputra, R., Marta, I. A., Bakhtiar, S., \& Nata, A. D. (2020). Nutritional Status Effect on Object Control Ability in Children Age 5 to 6 Year. Kinestetik: Jurnal Ilmiah Pendidikan Jasmani, 4(2), 25-32. https://doi.org/10.33369/jk.v4i2.12175

Raibowo, S., Adi, S., \& Hariadi, I. (2020). Efektivitas dan Uji Kelayakan Bahan Ajar Tenis Lapangan Berbasis Multimedia Interaktif. Jurnal Pendidikan: Teori, Penelitian Dan Pengembangan, 5(7), 944-952. https://doi.org//10.17977/jptpp.v5i7.137 26

Raibowo, S., Ilahi, B. R., Prabowo, A., Nopiyanto, Y. E., \& Defliyanto. (2021). Penguasaan Keterampilan Dasar Futsal UKM FORKIP Universitas Bengkulu. Jurnal Pendidikan Kesehatan Rekreasi, 7(2), 333-341. https://doi.org/10.5281/zenodo.4897656

Raibowo, S., Jatra, R., Prabowo, A., Nopiyanto, Y. E., \& Ilahi, B. R. (2021). Anxiety and Concentration of Tennis Chair Umpire. Halaman Olahraga Nusantara (Jurnal Ilmu Keolahragaan), 4(Ii), 271-281. https://doi.org/10.31851/hon.v4i25640

Sari, M. R., \& Kurniawan, A. (2018). Gambaran Manajemen Stres Terhadap Kecemasan Kompetitif Pada Atlet Panahan. Jurnal Psikologi Klinis Dan Kesehatan Mental, 7(3), 63-81.

Septiyanto, A., \& Suharjana. (2016). Pengaruh Metode Latihan Imagery dan Konsentrasi Terhadap Ketepatan Floating Service Atlet Bola Voli DIY. Jurnal Cakrawala Pendidikan, 35(3), 412-420.

https://doi.org/10.21831/cp.v35i3.8249

Sholikhin, Nurkholis, \& Jannah, M. (2019).
Pengaruh Latihan Progresive Muscle Relaxation dan Imagery Terhadap Konsentrasi, Tingkat Kecemasan, dan Ketepatan Memanah. Jendela Olahraga, 4(1), $18-25$. https://doi.org/10.26877/jo.v4i1.2952

Siahaan, D. (2017). Pengaruh Latihan Horizontal Swing Dan Latihan Side Lateral Raise Terhadap Kemampuan Forehand Drive Dalam Permainan Tenis Lapangan. Jurnal Prestasi, 1(2), 23-28. https://doi.org/10.24114/jp.v1i2.8060

Sin, T. H., \& Aprinanda, M. (2020). The Impact of Concentration Toward Soccer Player Shooting Ability of Soccer School Batuang Taba Padang City. International Journal of Research in Counseling and Education, 4(1), 35. https://doi.org/10.24036/00245za0002

Syafrial, Sugihartono, T., Yarmani, Arwin, Putri, R. E., Novriansyah, \& Defliyanto. (2020). Relationship of Physical Activity to Total Fat Mass of Lecturers and Employes Bengkulu University. Kinestetik: Jurnal Ilmiah Pendidikan Jasmani, $\quad$ 4(2), 108-113. https://doi.org/10.33369/jk.v4i2.10573

Tache, N., Lubis, L., \& Saputra, L. (2017). Concentration Level Differences between Athletes of Body Contact and Non-Body Contact Sports. Althea Medical Journal, 4(3), 396-401. https://doi.org/10.15850/amj.v4n3.1188

Tangkudung, J. (2018). SPORT PSYCHOMETRICS: Dasar-Dasar dan Instrumen Psikometri Olahraga (1st ed., Issue October). Raja Grafindo Persada.

Terry, P. C., \& Karageorghis, C. I. (2011). Music in Sport and Exercise. In The New Sport and Exercise Psychology Companion (Issue January 2011, pp. 359-380).

Triananda, A., Syafrial, \& Nopiyanto, Y. E. (2021). Karakteristik Psikologis Atlet PON Bengkulu Ditinjau dari Cabang Olahraga Individu. Sport Gymnastics: Jurnal Ilmiah Pendidikan Jasmani, 2(1), 126-137.

https://doi.org/10.33369/gymnastics.v2i 1.14862

Wahib, A. A., Tomoliyus, Hariadi, I., \& Adi, S. (2021). The Psychology and Motivation of The Junior Badminton 
Athlete in The Competition. PalArch's

Journal of Archaelogy of

Egypt/Egyptology, 18(9).

Widiastuti, I. A. E., Irawati, D., \& Lestrarini,

I. A. (2017). Hubungan Nilai Aktivitas

Fisik dengan Kadar Trigliserida dan

Kolesterol HDL Pada Pegawai Fakultas

Kedokteran Universitas mataram.

Jurnal Kedokteran Unram, 6(4), 18-21. 